Izvorni znanstveni rad - UDK - 159.942-058.833(55)

173.1

159.922.1.072(55)

\title{
Effects of Existential Issues Training on Marital Communication Among Iranian Women
}

\author{
Seyed Mohammad Kalantarkousheh \\ Allameh Tabataba'i University, Iran
}

\begin{abstract}
Marital communication is acknowledged as a crucial indicator of matrimonial quality, and has undergone studies in recent times with respect to its determinants. While existing literature has focused on the value of existential issues from four existential counseling theories in improving matrimonial quality, there is a dearth of experimental research to substantiate the effects of the existential issues on marital communication. This study aims to fill the gap and highlight the potential of the existential issues by investigating the effects of a psycho-educational training, based on existential issues, on marital communication, among Iranian women. For the present study, sixty Iranian married women were randomly selected for experimental and control groups. During five sessions, the experimental group received psycho-educational training based on existential issues. The results of the study show significant enhancements in marital communication of the participants.
\end{abstract}

Keywords: existential issues, training, psycho-education, marital communication

\section{Introduction}

Good communication is a known driver and even an indicator of matrimonial quality. In expert opinion, communication, or the process of transmitting and receiving verbal and non-verbal signals or messages, is regarded as a principal vehicle (Lerner, 2003) and cornerstone (Eckstein \& Goldman, 2001) in the attainment of marital quality. Thus, studies on matrimonial quality stipulate 'good communication between spouses' as an essential mode of matrimonial adjustment and satisfaction (Rehman, et al., 2011; Resnick, 2007), wherein the most significant determinants are: meaning in life, differentiation of self, anxiety, negative events in

Seyed Mohammad Kalantarkousheh, Department of Counselling and Guidance, Faculty of Psychology and Education, Allameh Tabataba'i University, Iran. E-mail: Kalantar.counseling@gmail.com. 
matrimony, self-esteem, and a high level of constructive communication. Illustratively, thus, the relationship between these determinants and the quality of marital communication is as follows:

(i) Decreased feelings of usefulness in the marriage or in the partner's life and a lack of 'meaning in life', or signification of marriage in life. These are ubiquitous sources and causes of poor marital communication (Kalantarkousheh \& Hassan, 2010b; Zietlow \& Sillars, 1988).

(ii) 'Differentiation of Self' - Bowen's (1978) conceptualization of the differentiation of self has crucial influences on marital communication. He states that the level of differentiation has a proportional affect on one's capacity to initiate and sustain a mature communication with one's spouse. Further, differentiation of self is most aided and nurtured by factors such as a prided sense of responsibility, authority and confidence in one's role in decision-making within the marriage (Gubbins, Perosa, \& Bartle-Haring, 2010; Kerr \& Bowen, 1988).

(iii) Negative Anxiety - Kouros and Cummings (2011) point out that negative anxiety, either over the partner or any other matter, has an adverse impact on marital communication and on the quality and the quantity of intimate time couples spend with each other (Gubbins et al., 2010; Ledermann, Bodenmann, Rudaz, \& Bradbury, 2010).

(iv) Negative Events in Marriage, and their Recollection - Over and above the damaging effect of negative events that had occurred in the marriage, reminding each other of those events is a greater destructive factor for the quality of marital communication (Cohan \& Cole, 2002; Tesser \& Beach, 1998).

(v) Self-Esteem - Studies have indicated a significant positive association between self-esteem and marital communication (Cornelius, Shorey, \& Beebe, 2010). Miller (2010) explains that self-esteem, in the context of matrimony, is particularly subject to the acceptance of negative experiences in the past rather than the evasion of it, wherein such acceptance of experienced events brings a positive impact on sustained marital communication. Miller (2010) also adds that this strategy of acceptance enables a person to look ahead at the future with optimism and hope, which is reflective of a positive attitude towards existential time.

(vi) High Level of Constructive Communication - Studies have validated that spouses who deliver a high level of constructive communication in building marital harmony and support - and through wittiness, sympathy and consideration - enjoy higher qualities of communication in their marriage compared to those who resort to destructive measures such as accusatory, condemning and oppressive communication (Feeney, 2002; Rauer \& Volling, 2005).

Incidentally, the above mentioned determinants of marital communication are also found as the core constituents of existential approaches, which have a potential for the counseling process (Kalantarkousheh \& Hassan, 2010a). Cooper (2003) 
highlighted four contemporary existential counseling theories - namely: Daseinsanalysis, Logotherapy, the American Existential Humanistic theory, and the Existential Humanistic Theory - wherein each lays emphasis on a number of existential issues. In a defining study of the application of existential counseling theories, Kalantarkousheh, Hassan, Kadir, \& Talib (2011a) extracted the core existential issues from all four existential counseling theories to be applied towards enhancing matrimonial quality, as illustrated in Table 1.

Table 1. Extracted Existential Issues from Existential Counseling Theories, for Application in Enhancing Marital Communication (Kalantarkousheh et al., 2011a)

\begin{tabular}{|c|c|c|c|}
\hline Authors & Theory & $\begin{array}{l}\text { Key concepts of the } \\
\text { theory }\end{array}$ & $\begin{array}{c}\text { Extracted existential } \\
\text { issues }\end{array}$ \\
\hline $\begin{array}{l}\text { Ludwig } \\
\text { Binswanger } \\
(1881-1966) / \\
\text { Medard Boss } \\
(1903-1990)\end{array}$ & Daseinsanalysis & $\begin{array}{l}\text { - } \quad \text { Being in the world } \\
\text { with others } \\
\text { - } \quad \text { Freedom }\end{array}$ & $\begin{array}{ll}\text { - } & \text { Existential I-thou } \\
& \text { relationship } \\
\text { - } & \text { Existential freedom }\end{array}$ \\
\hline $\begin{array}{l}\text { Viktor Frankl } \\
\text { (1905-1997) }\end{array}$ & Logotherapy & $\begin{array}{ll}- & \text { Meaning of life } \\
\text { - } & \text { Time } \\
\text { - } & \text { Freedom }\end{array}$ & $\begin{array}{ll}\text { - } & \text { Existential meaning } \\
\text { - } & \text { Existential time } \\
\text { - } & \text { Existential freedom } \\
& \text { and responsibility } \\
\end{array}$ \\
\hline $\begin{array}{l}\text { Rollo May } \\
(1904-1994)\end{array}$ & $\begin{array}{l}\text { The American } \\
\text { existential } \\
\text { humanistic } \\
\text { approach }\end{array}$ & $\begin{array}{l}\text { - Encountering real } \\
\text { anxieties }\end{array}$ & $\begin{array}{ll}\text { - } & \text { Existential anxiety } \\
\text { - } & \text { Existential freedom }\end{array}$ \\
\hline $\begin{array}{l}\text { Emmy Van } \\
\text { Deurzen } \\
(1951-)\end{array}$ & $\begin{array}{l}\text { The British } \\
\text { school of } \\
\text { existential } \\
\text { analysis }\end{array}$ & $\begin{array}{l}\text { - Being in the world } \\
\text { with self and others }\end{array}$ & $\begin{array}{l}\text { - Existential I-thou } \\
\text { relationship }\end{array}$ \\
\hline
\end{tabular}

Table 1 clearly shows that the core existential issues in existential counseling theories are largely similar to the determinants of marital communication mentioned earlier. For instance, 'meaning of life' is one of the core constituents in both existential counseling and marital communication (Frankl, 1984); Bowen's (1978) differentiation of self, and its link to decision making and responsibility within a marriage, can be discussed in the context of existential issues such as freedom and responsibility (Frankl, 1984; Kalantarkousheh, 2011; May, 1977); anxiety is both a marital as well as an existential issue (Kalantarkousheh \& Hassan, 2009; May, 1977; van Deurzen, 2002); negative events in life as well as marriage both fall into the scope of existential time (Frankl, 1984; Kalantarkousheh, Hassan, Kadir, \& Talib, 2011b); and a high level of marital communication fits into the wide scope of existential 'I-Thou' communication (van Deurzen, 1998). 
Interestingly, a study in Iran shows that the rate of differention of self is low in Iranian women in comparison to Iranian men (Younesi, 2004). Additionally, Neshat-Doost and his colleagues conducted a research to investigate the relationship among 389 married Iranian women who were randomly selected for the purpose (Neshat-Doost, Mehrabi, Kalantari, Palahang, \& Soltani, 2008). Marital satisfaction scales, Oxford happiness scale with a demographic questionnaire were used to gather the data. The results show that there is a significant positive relationship between happiness and matrimony. Further, in a research, Kalantarkousheh, Hassan, Kadir, \& Talib (2012) reported that the existential issues training improved marital satisfaction of Iranian participated women.

Such prominent equivalence between the determinants of marital communication and the core existential issues from existential counseling theories raises the awareness that existential issues may correspondingly enhance marital communication that yields greater matrimonial quality. Subsequently, this research aimed to study the effects of psycho-educational training, based on existential issues, on marital communication. Based on the previously mentioned aim, there are two hypotheses. The first one is "The score of marital communication in the post-test and follow-up test is significantly higher than that in the pre-test, in the experimental group", and the second one is "The score of marital communication in the follow-up test of the experimental group is significantly higher than that in the follow-up test of the control group".

\section{Methods}

\section{Participants}

The sample of this interventional study comprised of married women who volunteered and registered for a psycho-educational training on existential issues held at two health centers in the Tehran Municipality of Iran. Information on the training was posted and disseminated at the two centers, with the following selection criteria: (a) women between 20 and 40 years of age; (b) completion of at least high school education; (c) in a marriage of 10 years or less; and (d) no medical history of mental disorders.

Registration for participation entailed filling out a questionnaire that enabled ranking responses on a 5-point Marital Communication Scale. A total of 60 married women who scored below 4 (out of 5) on the scale were finally and randomly selected, with 30 women in the experimental group and 30 others in the control group. Participants' age ranged from 25 to 40 years $(M=34.5, S D=4.61)$. Educational qualifications in the experimental group were the equivalent of diplomas for $43 \%$ of participants, and master's degrees for the rest, while the 
control group had $46 \%$ of respondents with diplomas, and the rest with master's degrees. With regards to employment, $14 \%$ and $13 \%$ of participants in the experimental and control group, respectively, were employed. All sessions in the course of the study were offered free of charge to the participants.

\section{Measures of Marital Communication}

To evaluate the training program of this study, a Marital Communication Scale Questionnaire with ten items from the ENRICH (Evaluation and Nurturing Relationship Issues, Communication and Happiness) was administered at the beginning (pre-test) and the end (post-test) of the program, and then three weeks after the program's completion (follow-up test, with ten questions - to elicit responses on queries such as: "I am very satisfied with how my partner and I talk to each other" and "My partner sometimes makes comments that put me down". Only in the pre-test questionnaire, six additional demographic items (namely: age, job, education, duration of marriage, family income and the number of children) were included for the purpose of conducting a homogeneity test on the two groups. All responses were scored on a five-point Likert scale. It is worth to mention that in the present study, Cronbach alpha is .76 for marital communication scale.

\section{Program of the Study}

This study aimed to examine the effects of existential issues training on enhancing marital communication. The research entailed a randomized control design, with a pre-test, post-test and a follow-up test to gauge the effects of the training for both groups. The experimental group was provided the psychoeducational training program over a total of five training sessions of approximately 1.5 hours each, on a weekly basis, after they had signed and provided informed consent forms, upon the assurance of confidentiality. It is worth to mention that the women who participated in the control group received the same training after the follow-up test. All sessions consisted of a lecture and subsequent discussions on existential issues extracted from the four contemporary existential theories of counseling. The existential issues covered in the course of the program were as follows:

First Session: "Meaning of life". In this session, participants were provided with a thorough understanding of the potential meaning in their matrimony, and the signification of marriage in their lives. It is important to say that existential couple counselors believe family change most frequently occurs when spouses are able to find a meaning, reason, and purpose for the change (Frankl, 1988; Lantz, 2004). They declare that important and lasting change will more often happen when individuals experience motivation to change, and that the counselor's most important responsibility is to assist couples to become more aware of the potentials 
of meaning that can be actualized by counseling sessions (Frankl, 1988; Lantz, 2004).

Second Session: "Existential freedom and responsibility". Here, participants were guided to reflect and focus on concepts of existential freedom and responsibility on account of possible limitations of the same in their own lives. Particular attention was given to build an awareness of oneself as one who makes her own life-decisions and, thus, is fully empowered with the responsibility for those decisions.

Third Session: "Existential anxiety". This module aimed to provide multifaceted support to participants in effectively facing anxieties in their lives. In the training, the participants were informed that a human being should embrace anxiety as a part of experience. We as human beings should explore it, experience it, engage it, and redirect it into constructive activities - we should not avoid it (van Deurzen, 2002).

Fourth Session: "Existential time". In this session, time was presented in all its signification and segmentation - namely: present, past and future - and participants were given new attitudes towards each segment of time in their lives, with respect to their responsibilities in each. From the existential point of view, the individual in one time lives in three times: "by memory he has brought his past with him into the present and by anticipation and imagination he has already laid hold on his future and projects himself into it" (Macquarrie, 1973, p. 156). From the existential perspective, paying close attention to three times in one time is an exceptional human character. However, a human being, at the extreme end of the scale, may come to be now-centered, which is the main characteristic of a thing or animal (Macquarrie, 1973). Existentialists try their best to guide others to self-awareness of human conditions, meaning that, past and future are real concepts and we as human beings allow them to live in the present.

Fifth Session: "Existential 'I-thou' communication". Here, participants learned about the characteristics of human communication based on 'I-Thou' communication. The women who participated were confirmed that a human being needs to do and act in a manner to prevent I-Thou communication from being reduced to I-It communication.

\section{Homogeneity Tests}

Individual demographic variables (namely: age, family income, and the number of children) and the dependent variable (namely, marital communication) were statistically tested (Levene's test), for both groups. The results did not reveal any significant difference between the experimental and control groups in terms of these variables. Assuredly, any reported changes in matrimonial satisfaction responses, in going from the pre-test to the post-test, would have only resulted from 
the existential training provided through the study program. The results of the homogeneity test are illustrated in Table 2.

Table 2. Homogeneity Tests of Marital Communication and Demographic Characteristics between the Experimental and Control Groups

\begin{tabular}{|c|c|c|c|c|c|}
\hline \multirow[t]{2}{*}{ Variables } & \multicolumn{2}{|c|}{$\begin{array}{l}\text { Experimental group } \\
(N=30)\end{array}$} & \multicolumn{2}{|c|}{$\begin{array}{l}\text { Control group } \\
(N=30)\end{array}$} & \multirow{2}{*}{$\begin{array}{c}\text { Levene's tes } \\
\text { sig } \\
\end{array}$} \\
\hline & $M$ & $S D$ & $M$ & $S D$ & \\
\hline $\begin{array}{l}\text { Marital } \\
\text { communication }\end{array}$ & 2.97 & 0.32 & 2.99 & 0.35 & .67 \\
\hline Age & 35.00 & 4.38 & 34.70 & 4.85 & .80 \\
\hline $\begin{array}{l}\text { Duration of } \\
\text { marriage }\end{array}$ & 7.46 & 1.43 & 7.83 & 1.57 & .70 \\
\hline Family income & 803.30 & 204.23 & 733.30 & 214.85 & .60 \\
\hline $\begin{array}{l}\text { Number of } \\
\text { children }\end{array}$ & 1.53 & 0.89 & 156 & 0.93 & .83 \\
\hline
\end{tabular}

\section{Results}

To test the first hypothesis (H1), a repeated measure ANOVA, with Greenhouse-Geisser correction, was performed to compare the differences in the mean scores for marital communication obtained during the pre-, post- and followup tests conducted on the experimental group. As shown in Table 3, the test revealed that there was a statistically significant difference in the mean test score of the three measurements in the experimental group $\left(\mathrm{F}(1,59)=80.38, p<.01, \eta_{\mathrm{p}}{ }^{2}=.73\right)$. Thus, the first research hypothesis, namely "the score of marital communication in the post-test and follow-up test is significantly higher than that in the pre-test, in the experimental group" was retained on the basis of these results.

Table 3. Repeated Measure ANOVA for Marital Communication of the Experimental Group $(\mathrm{N}=30)$

\begin{tabular}{llccccc}
\hline Groups & Tests & $M^{a}$ & $S D$ & $\begin{array}{c}\text { Mean } \\
\text { square }\end{array}$ & $F$ & $\begin{array}{c}\text { Effect } \\
\text { size }\end{array}$ \\
\hline \multirow{3}{*}{ Experimental } & 1. Pre- & $2.97_{2}$ & 0.33 & & & \\
& 2. Post- & 3.293 & 0.30 & 2.23 & $80.38^{* *}$ & 1.64 \\
& 3. Follow-up & 3.35 & 0.29 & & & \\
\hline
\end{tabular}

a Numbers near Means show significant differences $(\mathrm{p}<.01)$.

Further, as shown in Table 3, mean difference $(M D)$ estimations between the tests conducted on the experimental group showed that the post-test $M D$ was higher 
than that of the pre-test $(M D=0.32)$, and the follow-up test $M D$ was higher than that of the post-test $(M D=0.05)$.

Next, the independent $t$-test was used to examine the second hypothesis, namely, "The score of marital communication in the follow-up test of the experimental group is significantly higher than that in the follow-up test of the control group". As shown in Table 4, the independent $t$-test revealed that the follow-up test scores were significantly higher for the participants of the experimental group than they were for those in the control group $(t(58)=4.09$, $p<.01)$. Therefore, the second hypothesis was retained on the basis of these results.

Table 4. Independent t-Test for Marital Communication Follow-up Test Scores of the Experimental and Control Groups

\begin{tabular}{lccccc}
\hline Variable & $\begin{array}{c}\text { Follow-up test } \\
\text { score }\end{array}$ & $\begin{array}{c}\text { Control } \\
\text { group } \\
(N=30)\end{array}$ & $\begin{array}{c}\text { Experimental } \\
\text { group } \\
(N=30)\end{array}$ & $\begin{array}{c}t \\
d f=58\end{array}$ & Cohens' d \\
\hline Marital & $M$ & 3.01 & 3.35 & $4.09^{* *}$ & 1.00 \\
communication & $S D$ & 0.34 & 0.29 & & \\
\hline
\end{tabular}

${ }^{* *} p<.001$.

\section{Discussion and Conclusion}

This cross-sectional, interventional study was an investigation of the effects of psycho-educational awareness training based on the existential issues to enhance marital communication among Iranian women. The training program administered in the study focused mainly on providing information to aid re-conceptualizations on critical existential issues, and to construct positive and empowering attitudes with respect to those issues. In the course of the training, awareness was created among the women participants regarding their control over their own existential characteristics, through functional conceptualizations of: creating meaning or signification of marriage in the context of their lives, recognizing their own ability to decide and enhance their sense of responsibility within their marriage, determining courses of changing negative anxiety to positive one, constructing new perspectives on all three conceptualizations of existential time, and examining the criteria of human and non-human communication. In due course of the study, training on existential issues was found to have an augmenting and causal effect on marital communication, among the women participants.

The findings of this study are supported by a number of prior studies, especially by those of Kalantarkousheh et al. (2011a) and Kalantarkousheh, Hassan, Kadir, \& Talib (2012), in that: psycho-educational training based on existential issues has a positive impact on marital communication and satisfaction. 
This study's findings, with respect to the role of existential issues in marital communication, are also harmonized with those of earlier studies that emphasized that 'meaning of life' is a deciding determinant of matrimonial communication quality (Kalantarkousheh \& Hassan, 2010a; Zietlow \& Sillars, 1988); that Bowen's 'differentiation of self' positively affects marital communication (Bowen, 1978), wherein acknowledging personal responsibility and commitment to marital decision making yields a high degree of self-differentiation (Gubbins et al., 2010); and that negative anxiety exerts a correspondingly negative impact on marital communication (Kouros \& Mark Cummings, 2011; Ledermann et al., 2010).

In further application of the awareness of existential issues in enhancing marital communication, the training provided women with information that effectively facilitated an attitudinal change that would turn negative anxiety into its positive equivalent; and an awareness of 'existential time', which would change their perspective towards negative life events and enable them to honor their past time and, consequently, use the past as a means to enable personal growth in the future by using negative life events as a springboard for optimism. Herein, such application of existential elements in enhancing marital communication in this research is substantiated by findings of earlier studies that illustrated: the negative association of negative life events with the quality of marital communication (Bradbury, Cohan, \& Karney, 1998; Cohan \& Cole, 2002); the positive association of optimism with marital communication through improved self-esteem (Cornelius et al., 2010; Miller, 2010); and the positive impact of the yields of 'I-Thou' communication - such as harmony, support, wittiness, sympathy, and consideration - in enhancing marital communication (Feeney, 2002; Rauer \& Volling, 2005).

Conclusively, the highly useful and applicable findings of the study offer a strong basis for future research. For instance, the positive impact of existential training on marital communication - and, thus, on matrimonial quality - open the possibility of offering such training as an intervention in 'couple counseling' sessions, and as 'pre-marriage education' that would serve as a preventive measure for alleviating factors that adversely affect marriages.

The limitation of this study lies in the single gender of the participants, wherein studies on males would be necessary to establish the benefits of psychoeducational training on existential issues in improving marital communication for both partners in a marriage. Additionally, an Iranian sample population implies that the results of this study may not be widely generalizable to populations in other countries and cultures.

Consequently, the scope of future work would require the application of existential training to enhance matrimonial communication in a larger and broadly stratified sample, on couples, various socio-cultural settings, or in a longitudinal study. 


\section{References}

Bowen, M. (1978). Family therapy in clinical practice. New York: Jason Aronson.

Bradbury, T.N., Cohan, C.N., \& Karney, B.R. (1998). Optimizing the research for understanding and preventing marital dysfunction. Cambridge: Cambridge University Press.

Cohan, C.L., \& Cole, S.W. (2002). Life course transitions and natural disaster: Marriage, birth, and divorce following Hurricane Hugo. Journal of Family Psychology, 16(1), 14-25.

Cooper, M. (2003). Existential therapies. London: Sage Publications Ltd.

Cornelius, T.L., Shorey, R.C., \& Beebe, S.M. (2010). Self-reported communication variables and dating violence: Using Gottman's marital communication conceptualization. Journal of Family Violence, 25(4), 439-448.

Eckstein, D., \& Goldman, A. (2001). The Couples' Gender-Based Communication Questionnaire (CGCQ). The Family Journal, 9(1), 62-74. doi: $10.1177 / 1066480701091014$

Feeney, J.A. (2002). Attachment, marital interaction, and relationship satisfaction: A diary study. Personal Relationships, 9(1), 39-55.

Frankl, V. (1984). Man's search for meaning: An introduction to logotherapy (I. Lasch, Trans.). New York: Touchstone.

Frankl, V. (1988). The will to meaning: Foundations and applications of logotherapy. New York: New American Library.

Gubbins, C.A., Perosa, L.M., \& Bartle-Haring, S. (2010). Relationships between married couples' self-differentiation/individuation and Gottman's model of marital interactions. Contemporary Family Therapy, 1-13.

Kalantarkousheh, S.M. (2011). Efficacy of existential freedom training in marital satisfaction of Iranian women Australian Journal of Basic and Applied Sciences, 5(12), 872-876.

Kalantarkousheh, S.M., \& Hassan, S.A. (2009, October). Anxiety and existential psychotherapy: A pragmatic approach. Paper presented at the International Conference on Social Science and Humanities, Singapore.

Kalantarkousheh, S.M., \& Hassan, S.A. (2010a, February). Existential theory as an essential ingredient of the counselling process. Paper presented at the International Conference on Humanities, Historical and Social Sciences, Singapore.

Kalantarkousheh, S.M., \& Hassan, S.A. (2010b). Function of life meaning and marital communication among Iranian spouses in University Putra Malaysia. Procedia-Social and Behavioral Sciences, 5, 1646-1649. 
Kalantarkousheh, S.M., Hassan, S.A., Kadir, R.A., \& Talib, M.A. (2011a). Manifestation of existential issues as a brilliant function for quality of matrimony. Journal of American Science, 7(5), 459-465.

Kalantarkousheh, S.M., Hassan, S.A., Kadir, R.A., \& Talib, M.A. (2011b). Sparkle of existential time as a sanctuary in marital counselling. Journal of American Science, 7(6), 690-694.

Kalantarkousheh, S.M., Hassan, S.A., Kadir, R.A., \& Talib, M.A. (2012). Effects of existential issues training on marital satisfaction among Iranian women. The New Educational Review, 28(2), 29-38.

Kerr, M.E., \& Bowen, M. (1988). Family evaluation. New York: Norton.

Kouros, C.D., \& Cummings, E.M. (2011). Transactional relations between marital functioning and depressive symptoms. American Journal of Orthopsychiatry, 81(1), 128-138.

Lantz, J. (2004). World view concepts in existential family therapy. Contemporary Family Therapy: An International Journal, 26, 165-178.

Ledermann, T., Bodenmann, G., Rudaz, M., \& Bradbury, T.N. (2010). Stress, communication, and marital quality in couples. Family Relations, 59(2), 195-206.

Lerner, L.N. (2003). A qualitative examination of what couples feel are important components in communication. Dissertation Abstracts International: Section $B$. Sciences \& Engineering. 64(1-B), 465.

Macquarrie, J. (1973). Existentialism. New York: Pelican Books.

May, R. (1977). The meaning of anxiety. New York: Norton.

Miller, T.W. (2010). Concluding comments and future considerations for stressful life events and transitions across the life span. In T.W. Miller (Ed.), Handbook of stressful transitions across the lifespan, 663-673.

Neshat-Doost, H.T., Mehrabi, H.A., Kalantari, M., Palahang, H., \& Soltani, I. (2008). Predicting factors of happiness in wives of Mobarekeh steel company personal in Iran. Journal of Family Research, 3(3), 669-681.

Rauer, A.J., \& Volling, B.L. (2005). The role of husbands' and wives' emotional expressivity in the marital relationship. Sex Roles, 52(9), 577-587. 
Rehman, U.S., Janssen, E., Newhouse, S., Heiman, J., Holtzworth-Munroe, A., Fallis, E., \& Rafaeli, E. (2011). Marital satisfaction and communication behaviors during sexual and nonsexual conflict discussions in newlywed couples: A pilot study. Journal of Sex \& Marital Therapy, 37(2), 94-103.

Resnick, E. (2007). The relations among differing forms of psychopathology symptoms, couple communication, and relationship satisfaction. (Unpublished master's thesis). University of Maryland, College Park. Maryland.

Tesser, A., \& Beach, S.R.H. (1998). Life events, relationship quality, and depression: An investigation of judgment discontinuity in vivo. Journal of Personality and Social Psychology, 74(1), 36-52.

van Deurzen, E. (1998). Existential counselling in practice. London: Sage.

van Deurzen, E. (2002). Existential counselling \& psychotherapy in practice (2nd ed.). London: Sage.

Younesi, J. (2004). The role of cognitive distortion (Deterministic thinking) on Psychological pathology. Journal of Iranian Psychological Association, 3(12), 73-86.

Zietlow, P.H., \& Sillars, A.L. (1988). Life-stage differences in communication during marital conflicts. Journal of Social and Personal Relationships, 5(2), 223-245.

\section{Učinci treninga temeljenog na egzistencijalnim principima na kvalitetu bračne komunikacije u iranskih žena}

\section{Sažetak}

Bračna je komunikacija ključni indikator bračne kvalitete, zbog čega se u novije vrijeme proučavaju njezine karakteristike. Postojeća literatura naglašava vrijednost egzistencijalnog pristupa prema četiri egzistenicijalne teorije u savjetovanju, usmjerene na poboljšanje bračne kvalitete, no nedostaju eksperimentalna istraživanja koja bi potvrdila njezine efekte u bračnoj komunikaciji. Cilj je ovoga istraživanja prevazilaženje te manjkavosti i naglašavanje snage egzistencijalnih principa. Ispitan je učinak psiho-edukacijskog treninga temeljenog na egzistencijalnim principima na bračnu komunikaciju kod iranskih žena. U ovom je istraživanju sudjelovalo 60 udatih Iranki koje su slučajnim odabirom podijeljene u eksperimentalnu i kontrolnu skupinu. Eksperimentalna je skupina kroz pet susreta sudjelovala u psiho-edukacijskom treningu temeljenom na egzistencijalnim principima. Rezultati istraživanja pokazali su značajna poboljšanja u bračnoj komunikaciji.

Ključne riječi: egzistencijalni principi, trening, psiho-edukacija, bračna komunikacija

Primljeno: 15.06.2011. 